\title{
Ten years of fluxes and stand growth in a young beech forest at Hesse, North-eastern France
}

\author{
André GRANIER ${ }^{* 1}$, Nathalie BRÉDA ${ }^{1}$, Bernard LONGDOZ ${ }^{1}$, Patrick GRoss ${ }^{1}$, Jérôme NGAO ${ }^{2}$ \\ ${ }^{1}$ UMR INRA-UHP Écologie et Écophysiologie Forestières, INRA Centre de Nancy, 54280 Champenoux, France \\ ${ }^{2}$ UMR Écologie, Systématique et Évolution, Université Paris-Sud XI, Bâtiment 362, 91405 Orsay Cedex, France
}

(Received 12 December 2007; revised version 8 April 2008; accepted 26 June 2008)

Keywords:

Carbon balance /

evapotranspiration /

climate /

biomass increment /

interannual variability /

net primary productivity /

drought /

Fagus sylvatica

\begin{abstract}
- Water and carbon fluxes, as measured by eddy covariance, climate, soil water content, leaf area index, tree biomass, biomass increment (BI), litter fall and mortality were monitored for 10 successive years in a young beech stand in Hesse forest (north-eastern France) under contrasting climatic and management conditions.

- Large year-to-year variability of net carbon fluxes (NEE) and to a lesser extent, of tree growth was observed. The variability in NEE (coefficient of variation, $\mathrm{CV}=44 \%$ ) was related to both gross primary production (GPP) and to variations in total ecosystem respiration (TER), each term showing similar and lower interannual variability $(\mathrm{CV}=14 \%)$ than NEE. Variation in the annual GPP was related to: (i) the water deficit duration and intensity cumulated over the growing season, and (ii) the growing season length, i.e. the period of carbon uptake by the stand. Two thinnings occurring during the observation period did not provoke a reduction in either GPP, water fluxes, or in tree growth. Interannual variation of TER could not be explained by any annual climatic variables, or LAI, and only water deficit duration showed a poor correlation. Annual biomass increment was well correlated to water shortage duration and was significantly influenced by drought in the previous year.

- The relationship between annual NEE and biomass increment (BI) was poor: in some years, the annual carbon uptake was much higher and in others much lower than tree growth. However this relationship was much stronger and linear $\left(r^{2}=0.93\right)$ on a weekly to monthly time-scale from budburst to the date of radial growth cessation, indicating a strong link between net carbon uptake and tree growth, while carbon losses by respiration occurring after this date upset this relationship.

- Despite the lack of correlation between annual data, the NEE and BI cumulated over the 10 years of observations were very close.

- On the annual time-scale, net primary productivity calculated from eddy fluxes and from biological measurements showed a good correlation.
\end{abstract}

\author{
Mots-clés : \\ bilan de carbone / \\ évapotranspiration / \\ climat / \\ accroissement en biomasse / \\ variabilité interannuelle / \\ productivité primaire nette / \\ contrainte hydrique / \\ Fagus sylvatica
}

Résumé - Dix années de mesures de flux et de croissance dans une jeune hêtraie du nord-est de la France, en forêt de Hesse.

- Les flux d'eau et de dioxyde de carbone, mesurés par la méthode des corrélations turbulentes, le climat, le contenu en eau du sol, l'indice foliaire, la biomasse et l'accroissement en biomasse (BI) des arbres, les chutes de litière et la mortalité ont été suivis en continu pendant 10 années successives dans une jeune hêtraie de la forêt de Hesse (nord-est de la France) en conditions de climat et de gestion contrastées.

- Une forte variabilité interannuelle des flux nets de carbone (NEE) et dans une moindre mesure de la croissance des arbres ont été observées. La variabilité de NEE (son coefficient de variation, CV = $44 \%$ ) a été mise en relation avec celles de la productivité primaire brute (GPP) et de la respiration totale de l'écosystème (TER), chacun de ces deux termes montrant une variabilité similaire et plus faible $(\mathrm{CV}=14 \%)$ que pour NEE. Les variations de la GPP annuelle étaient sous la dépendance : (i) de la durée et de l'intensité du déficit hydrique cumulé sur la saison de végétation, (ii) la longueur de la saison de végétation, définie comme la période où le peuplement absorbe du dioxyde de carbone. Deux éclaircies pratiquées pendant la période de mesures n'ont pas provoqué de réduction ni de GPP, ni du flux d'évapotranspiration, ni de l'accroissement en biomasse du peuplement. Les

\footnotetext{
*Corresponding author: arganier@ nancy.inra.fr
} 
variations interannuelles de TER n'ont pu être expliquées par aucune des variables climatiques au pas de temps annuel, ni par le LAI, mais seulement par la durée du déficit hydrique du sol, mais avec une corrélation médiocre. L'accroissement annuel en biomasse était fortement corrélé à la durée de la contrainte hydrique de la même année mais aussi influencé de façon significative par la celle de l'année précédente.

- La relation entre la NEE annuelle et l'accroissement en biomasse (BI) n'était pas significative : selon les années, l'absorption de carbone par le peuplement était beaucoup plus forte ou plus faible que l'accroissement du peuplement. Toutefois, nous avons observé une corrélation beaucoup plus élevée et linéaire $\left(r^{2}=0,93\right)$ sur une base de temps hebdomadaire à mensuelle pendant la période allant du débourrement à la date d'arrêt de croissance radiale, ce qui indique un couplage fort entre l'acquisition du carbone et la croissance des arbres, alors que la perte de carbone par respiration en dehors de cette période découple cette relation.

- En dépit de l'absence de corrélation entre NEE et BI au pas de temps annuel, le cumul de NEE et celui de BI sur les 10 années ont été très proches.

- Par contre, la productivité primaire nette annuelle, calculée à partir des mesures de flux et biométriques sur le peuplement a montré un bon accord.

\section{INTRODUCTION}

Carbon and water flux exchanges within terrestrial ecosystems are now routinely measured using the eddy covariance technique. At the beginning of 2005, over 300 sites in the world were operating (see the Fluxnet web site http://daac. ornl.gov/FLUXNET/), a major proportion of them (186) having been installed in forests. This network covers a wide range of climatic and forest ecosystem types: sub-desertic, temperate, continental, boreal, dry and wet tropical areas, monospecific and mixed forests, managed and unmanaged forests. Eddy flux measurements allow the carbon balance to be quantified and they are powerful tools to study ecosystem sensitivity to climate and to parameterize soil-vegetation-atmosphere models.

The spatial and temporal variations in carbon and water fluxes and variations in their annual balance originate from two main sources, the vegetation type and the climate. Some cross-comparison investigations between the various terrestrial ecosystems were designed to classify terrestrial biomes into functional types regarding water and carbon fluxes, with respect to their range as well as their timing in the year. In particular, Law et al. (2002), analysing a large range of Fluxnet sites, forests and low-growing vegetation, demonstrated a large functional diversity within vegetation types in their flux response to climatic driving forces: radiation, temperature and water availability. A given forest type, and furthermore a given tree species, can show strong similarities in carbon dioxide and water flux response to climatic driving forces in different sites (for European beech see Granier et al., 2002). Even if there is a typical average response within a forest type, large year-to-year variability of carbon fluxes is often observed in sites where several years have been monitored.

However, because above-canopy flux measurements are still recent, the time series available are rather short. There are few long-term monitoring stations, with only 35 active sites since 1996, while the oldest eddy flux station is that of Harvard forest (Wofsy et al., 1993), which has been operating continuously since 1991. In forest stands, interannual variability of fluxes and biomass increment not only result from climate variability, which is generally high, but are also linked to the perennial characteristics of trees. In trees, as compared to the annual vegetation, this trait induces buffered and timelagged responses to environmental stresses, influencing both the structure and physiology during the following years (leaf area index, root distribution, carbon and nitrogen reserves, etc.). Unfortunately, this question is not well documented so far.

The two major mass fluxes exchanged between vegetation and the atmosphere are evapotranspiration (ET) and carbon (net ecosystem exchange, NEE) fluxes. The latter is the algebraic sum of photosynthetic processes (gross primary production, GPP) and of respiration losses (total ecosystem respiration, TER). The determinism in the variation of each flux is complex, as it combines the response of different compartments, from the soil to the leaves, with both autotrophic and heterotrophic components. The natural sources of variability are abiotic (temperature, radiation, vapour pressure deficit, water stress or excess, or fire) and biotic (diseases or pests), while anthropogenic sources are mainly due to management (thinning, regeneration, control of the understorey vegetation or species selection). Therefore, sources of the interannual variability of fluxes are multiple.

The beech stand of Hesse (north-eastern France), which is part of a site belonging to Carboeurope and Fluxnet networks, has been monitored continuously since 1996; moreover, contrary to most of the forest sites in these networks, this site is a young fast-growing forest subjected to frequent thinning that modifies the canopy structure and therefore light and water availability for the trees. The period investigated (1996-2005) covers contrasting climatic conditions and management practices.

This work aims to: (1) quantify the interannual variability of fluxes and tree growth, (2) investigate the main determinants of this variability: climate, phenology and management, and (3) compare the carbon budget measured using the eddy covariance technique, with the carbon gain of the stand obtained from inventories. 
Table I. Characteristics of the eddy covariance systems installed at Hesse. Dominant tree height is the mean height of the dominant trees.

\begin{tabular}{lccc}
\hline & $1996-1999$ & $2000-2005$ & \#EC3 \\
\hline Eddy covariance system & $\# \mathrm{EC} 1$ & \#EC2 & 20.5 \\
Measurement height $(\mathrm{m})$ & 18.5 & 40 & 0 (open-path) \\
Tube length $(\mathrm{m})$ & 33 & 17.5 (in 2004) & \\
Dominant tree height $(\mathrm{m})$ & 14.7 (in 1997$)$ & 4 & 6 \\
Tube diameter $(\mathrm{mm})$ & 4 & 5.1 & 0 \\
Flow rate $\left(1 \mathrm{~min}^{-1}\right)$ & 5 & 4.9 & $0.2,0.7,2.0,5.4,10.8,23.0$ \\
Time lag for $\mathrm{CO}_{2}(\mathrm{~s})$ & $0.2,0.7,2.0,8.0,12.0,18.5$ & \\
Heights of the $\mathrm{CO}_{2}$ profile $(\mathrm{m})$ & & & \\
\hline
\end{tabular}

\section{MATERIALS AND METHODS}

\subsection{Site}

The monitoring site was installed in the central part of Hesse forest $\left(48^{\circ} 0.453 \mathrm{~N}, 7^{\circ} 03.877 \mathrm{E}, 300 \mathrm{~m}\right.$ a.s.1.), in a 0.6 ha fenced experimental plot. The studied stand originated from natural regeneration; the trees were on average 40 years old ( \pm 5 years) in 2005 , composed of $95 \%$ European beech (Fagus sylvatica L.). The main accompanying tree species was Carpinus betulus and only sparse understorey vegetation was present, due to the high canopy closure. Average tree height was $12.8 \mathrm{~m}$ and $16.2 \mathrm{~m}$ in 1996 and 2005, respectively, and dominant tree height, defined here as the average height of the tallest $10 \%$ of trees, was $16.4 \mathrm{~m}$ and $18.3 \mathrm{~m}$ in 1996 and 2005, respectively. Other dendrometric characteristics are summarised in Table IV. According to the dominant height vs. age relationship, the site index belongs to the best fertility class defined by Schober, 1967 for German conditions and to the second fertility class of the English tables of production (Hamilton and Christie, 1971).

The soil type was intermediate between a luvisol and a stagnic luvisol. Clay contents ranged between $25 \%$ and $35 \%$ within the 0 $100 \mathrm{~cm}$ depth, and were about $40 \%$ below $100 \mathrm{~cm}$. Total soil carbon content was $10.07 \mathrm{~kg} \mathrm{~m}^{-2}$ within the 0 to $160 \mathrm{~cm}$ depth.

This forest is managed classically by the French forest service (ONF) and frequent thinning is carried out in this young high forest. One thinning was performed the year before the beginning of flux measurements at the end of 1995, the next was done in March 1999, and another at the end of 2004.

\subsection{Eddy covariance measurements}

Energy, vapour and $\mathrm{CO}_{2}$ flux were measured using eddy covariance at the top of a central tower. From 1996 to 1999, the measurement height was $18.5 \mathrm{~m}$; following storm Lothar on 26th December 1999, which destroyed the scaffolding tower but not the surrounding stands, a new tower was installed. Eddy covariance and climatic sensors were installed at a height of $23 \mathrm{~m}$.

The main flux measurement device was composed of a closed path IRGA (LI-6262 LI-COR Inc., Lincoln, Nebraska, USA) and a 3D Sonic anemometer (Solent R2, Gill Instruments Ltd., Lymington, UK). Air is sucked through the IRGA by 3 pumps (Model Rotronic 406G, Reciprotor, Skara, Sweden) connected in series, in a $4 \mathrm{~mm}$ diameter PTFE tube. Tube length and flow rate were $33 \mathrm{~m}$ and $51 \mathrm{~min}^{-1}$ until the end of 1999, and $40 \mathrm{~m}$ and $61 \mathrm{~min}^{-1}$ respectively since 2000. Data were processed with Edisol software (University of Edinburgh, UK). Half-hourly $\mathrm{CO}_{2}$ and $\mathrm{H}_{2} \mathrm{O}$ fluxes (called net ecosystem exchange (NEE), and evapotranspiration (E), respectively) were calculated following the recommendation of the Euroflux group (Aubinet et al., 2000).
The main characteristics of the different eddy covariance systems are given in Table I. In order to check whether the change in the measurement height in 2000 had induced a bias in the flux measurements, we added a second eddy covariance system to the tower (\#EC3) in 2003. It was installed at a height of $20.5 \mathrm{~m}$, i.e. $2.5 \mathrm{~m}$ below \#EC2. Both systems ran continuously for 61 consecutive days, from the end of August to the end of October. Over this period, the measured cumulated NEE amounted to -121 and $-128 \mathrm{~g} \mathrm{C} \mathrm{m}^{-2} \mathrm{y}^{-1}$, measured with \#EC2 and \#EC3, respectively, indicating no bias between the measurement heights.

The variation of $\mathrm{CO}_{2}$ concentration in the air was measured close to the tower, between the soil surface and the eddy covariance measurement level, at 6 heights every $2 \mathrm{~min}$. The duration of a complete cycle was $15 \mathrm{~min}$. These measurements allowed the $\mathrm{CO}_{2}$ storage in the air canopy to be calculated. The difference between two successive half-hours was calculated per unit of ground area (in $\mu \mathrm{mol} \mathrm{m} \mathrm{m}^{-2}$ $\mathrm{s}^{-1}$ ) and added to the raw $\mathrm{CO}_{2}$ flux measured above the stand. Data presented here take the $\mathrm{CO}_{2}$ storage term in the air into account. The night data were not corrected for low $\mathrm{u}^{*}$ conditions: Papale et al. (2006) showed that this correction had only a very limited impact on flux calculation at Hesse (ca. 5\%) as compared to other sites.

Gross primary production (GPP) was calculated from the relationship: GPP = NEE - TER, where TER is the total ecosystem respiration. This term was also estimated from the eddy flux measurements during periods without photosynthesis: during the night for the leafy periods, or during the whole day for the non-leafy periods. For the leafy periods, measured TER was extrapolated to the whole day using an exponential relationship fitted between TER and soil temperature measured at $-10 \mathrm{~cm}$.

\subsection{Climate and soil water conditions}

All the standard climatic variables were measured at the top of the eddy covariance tower from April 1996. Global, net and photosynthetically active radiation, rainfall, air temperature and humidity, and wind speed were measured every 10 s by a data logger (Model CR7 data logger, Campbell Scientific, Courtaboeuf, France) and $30 \mathrm{~min}$ averages were calculated and stored. Global radiation below the canopy, and soil temperatures were measured at depths of $-5,-10$, $-20,-40$ and $-80 \mathrm{~cm}$ at one central location, plus 6 replicates at $-10 \mathrm{~cm}$.

Soil water deficit during the growing season was assessed using a daily water balance model, described in Granier et al. (1999), which predicted the daily variation of soil water content in the root zone from climatic data (rainfall, global radiation, air temperature and humidity, and wind speed) measured above the stand, leaf area index, rooting and soil properties. This model calculates the vertical water 
Table II. The different tree samples for circumference measurements and biomass increment estimates.

\begin{tabular}{|c|c|c|c|}
\hline Sample & Area (ha) & $\begin{array}{c}\text { Number of trees } \\
\text { measured }\end{array}$ & Frequency \\
\hline Sub-sample & 0.12 & 540 & Weekly to monthly \\
\hline Experimental plot & 0.60 & 2700 & 1999 and 2003 \\
\hline Whole management plot & 21.25 & ca. $3600(4.4 \%)$ & 2000 and 2001 \\
\hline
\end{tabular}

fluxes (tree transpiration, understorey evapotranspiration, rainfall interception and drainage). Tree transpiration is calculated under the big-leaf assumption using the Penman-Monteith formula. Limitation of transpiration by stomatal regulation related to water stress and leaf area index variation was modelled according to Granier et al. (1999). Soil water balance outputs have been validated against neutron probe soil water content measurements for the stand studied (Granier et al., 2000a). Extractable soil water was $175 \mathrm{~mm}$ at a depth of $1.6 \mathrm{~m}$. From the calculated soil water content, soil water deficit duration (SWD) and a soil water deficit intensity index (WSI) were calculated as the number of days and as the sum of soil water deficit, respectively, below the threshold of 0.4 for relative extractable water (REW) during the vegetation period.

\subsection{Tree and stand growth}

In order to analyse the homogeneity of the stand studied, three areas of increasing spatial scales were compared. Frequency of the inventory was variable according to sample size, at intervals of $1-$ 2 weeks in the intensive measurement sub-sample ( $0.12 \mathrm{ha})$, to two measurements during the 10 -year investigation period in the whole stand (21.25 ha) (see Tab. II). The biomass (dry matter and carbon mass) of each tree compartment: trunk, roots and branches, were calculated from the breast height circumference using parabola-type allometric relationships. Coefficients of these relationships were fitted to data obtained from 21 trees by Ottorini and Le Goff (1998) in the same stand. The biomass increment (BI) was calculated as the difference between two consecutive biomass estimates.

At two dates (January 1999 and March 2004) the diameter at breast height of all the trees within the 0.6 ha experimental plot were measured (Tab. II).

From February 1996, circumference was measured manually at breast height $( \pm 1 \mathrm{~mm})$ in an area of 0.12 ha containing 540 trees. In December 2005, i.e. the end of the study period, only 306 trees remained: 128 trees were felled in spring 1999 and 66 in spring 2005 (thinning), while 40 suppressed trees died naturally. The frequency of those measurements was variable: at intervals of 7 to 15 days during the fast radial growth period (May and June) to 1-2 months during the period of growth cessation.

In order to quantify the spatial variability of tree biomass, another sample of trees (forest stand, see Tab. III) was measured at the beginning and at the end of 2000 , in 59 inventory plots $\left(450 \mathrm{~m}^{2}\right.$ each) located on a systematic network grid, $50 \mathrm{~m} \times 50 \mathrm{~m}$, in the $21.25 \mathrm{ha}$ surrounding the experimental plot (Bouriaud, 2003). Due to the homogeneity of the area studied, the difference in biomass between the 3 samples was very small: the 0.6 ha experimental plot contained $4 \%$ less biomass than the 21.25 ha surrounding it, while the 0.12 ha subsample contained $3 \%$ more.
Table III. Three estimates of tree biomass according to sample size (beginning 2000), values are in $\mathrm{g} \mathrm{C} \mathrm{m}^{-2}$. CI is the confidence interval.

\begin{tabular}{lccc}
\hline Sample & C biomass & $\%$ & CI $(p=0.05)$ \\
& & & \\
\hline Sub-sample (0.12 ha) & 4998 & 103 & 668 \\
Experimental plot (0.6 ha) & 4657 & 96 & - \\
Whole forest stand (21.25 ha) & 4856 & 100 & 269 \\
\hline
\end{tabular}

\subsection{Leaf area index and phenology}

Leaf area index was estimated from litter collected every year in 45 square $(0.5 \mathrm{~m} \times 0.5 \mathrm{~m})$ litter-traps evenly distributed on a grid covering the entire experimental plot. During leaf fall (mid-September to the end of November) litter was collected every week or every other week, depending on the amount of leaf fall inside the litter traps. Leaves were dried $\left(48 \mathrm{~h}\right.$ at $\left.60{ }^{\circ} \mathrm{C}\right)$ and weighed. A sub-sample of 5 out of the 45 traps was selected to measure leaf area/dry weight ratio. Leaf area was measured with a Delta-T Area meter (Cambridge, UK).

The growing season length (GSL) was defined as the period when net flux corresponded to $\mathrm{CO}_{2}$ fixation.

\subsection{Dead wood and fruit production}

Dead wood is an important biological component of this forest, especially due to the intensity and frequency of pre-commercial thinning: thinning occurs every 5 to 6 years in the young beech stands, each of them removing about $25 \%$ of the basal area. Firewood is extracted but branches remain in the forest. We estimated the amount of dead wood derived from thinning, from the successive inventories performed before and after thinning. The biomass of felled trees and its distribution in different tree compartments was estimated from the allometric relationships described above, and made it possible to calculate the dead wood biomass, mainly composed of branches and root systems, remaining in the plot.

Natural fall of dead branches and fruit production were estimated from monthly collections in the 45 litter traps. The beginning of fruit production was observed in 2002 when the trees were on average 36 years old.

Dry matter was converted to carbon mass from analyses made on different tree compartments: $1 \mathrm{~g}$ of dry matter contained on average $0.480,0.475$ and $0.500 \mathrm{~g} \mathrm{C}$ in leaf litter, wood and fruit, respectively.

\section{RESULTS}

\subsection{Climatic conditions during the 10 years}

The climate during the 10 years of measurements was very contrasting, depending on the years, especially the temperature and precipitation, while global radiation was not very variable $(\mathrm{CV}$, coefficient of variation $=$ standard deviation $/$ mean $<5 \%$ ). During this period, the mean annual air temperature was higher than the long-term (50 years) average (Fig. 1). Years 2000 and 2003 in particular, were warmer $\left(+2{ }^{\circ} \mathrm{C}\right)$ than the average. During the summer 2003 (June to August), mean monthly temperatures were the highest ever observed in this 


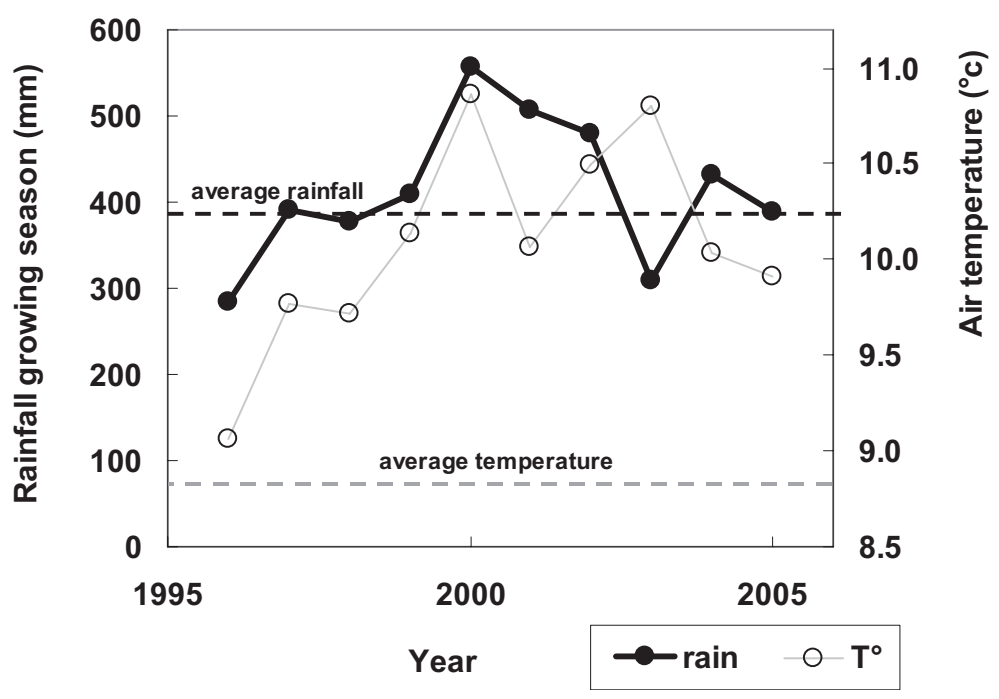

Figure 1. Cumulated rainfall during the growing season (May to September) and mean annual air temperature at Hesse from 1996 to 2005 . The horizontal dotted lines indicate long-term mean values.

Table IV. Average tree age (years), stand density $\left(n\right.$, stems ha $\left.{ }^{-1}\right)$, ground area $\left(\mathrm{G}, \mathrm{m}^{2} \mathrm{ha}^{-1}\right)$, total tree carbon biomass $\left(\right.$ biomC, $\left.\mathrm{g} \mathrm{C} \mathrm{m}^{-2}\right)$, leaf area index ( $\mathrm{LAI}, \mathrm{m}^{2} \mathrm{~m}^{-2}$ ), biomass increment (BI, $\left.\mathrm{g} \mathrm{C} \mathrm{m}^{-2} \mathrm{y}^{-1}\right)$, leaf and fine root production $\left(\mathrm{g} \mathrm{C} \mathrm{m}^{-2}\right)$, annual carbon fluxes (NEE, TER, GPP, from eddy covariance measurements, $\mathrm{g} \mathrm{C} \mathrm{m}^{-2} \mathrm{y}^{-1}$ ), growing season length (GSL, in days), evapotranspiration (E, mm), soil water deficit duration (SWD, days), autotrophic respiration (Raut, $\left.\mathrm{g} \mathrm{C} \mathrm{m}^{-2} \mathrm{y}^{-1}\right)$, mortality plus fruit production $\left(\mathrm{g} \mathrm{C} \mathrm{m}^{-2} \mathrm{y}^{-1}\right)$ at Hesse. Tree biomass is estimated at the end of each year. NPPec and NPPbio are two independent estimates of the annual NPP (in $\mathrm{g} \mathrm{C} \mathrm{m}^{-2} \mathrm{y}^{-1}$ ): NPPec is calculated from eddy covariance measurements and from autotrophic respiration estimates (Raut, see text); NPPbio is calculated as the sum of annual wood biomass increment (BI), plus leaves, fruit and fine root production and woody mortality. The growing season length is defined as the period during which the stand is gaining carbon, obtained from eddy covariance measurements. CV is the coefficient of variation $=100$ (standard deviation (SD)/mean).

\begin{tabular}{|c|c|c|c|c|c|c|c|c|c|c|c|c|c|c|c|c|c|c|}
\hline Year & $\overline{\text { Age }}$ & $n$ & $\mathrm{G}$ & BiomC & LAI & BI & $\begin{array}{c}\text { Leaf } \\
\text { production }\end{array}$ & $\begin{array}{l}\text { Fine roots } \\
\text { production }\end{array}$ & NEE & TER & GPP & GSL & $\bar{E}$ & SWD & Raut & NPPec & $\begin{array}{l}\text { Mortality + } \\
\text { fruit }\end{array}$ & NPPbio \\
\hline 1995 & 29 & 4588 & 19.88 & 4753 & & & & & & & & & & 30 & & & & \\
\hline 1996 & 30 & 4452 & 20.89 & 5087 & 5.7 & 320 & 137 & 60 & -194 & 930 & -1124 & 156 & 254 & 77 & 671 & 453 & 43 & 560 \\
\hline 1997 & 31 & 4450 & 22.61 & 5593 & 5.6 & 414 & 131 & 57 & -326 & 963 & -1289 & 157 & 317 & 20 & 695 & 594 & 0 & 602 \\
\hline 1998 & 32 & 4450 & 24.01 & 6001 & 7.4 & 361 & 155 & 67 & -76 & 1278 & -1354 & 158 & 347 & 37 & 923 & 431 & 34 & 618 \\
\hline 1999 Jan. & 33 & 3364 & 18.38 & 4617 & 4.8 & 531 & 120 & 52 & -321 & 1158 & -1479 & 152 & 404 & 0 & 836 & 643 & 53 & 756 \\
\hline 1999 Dec. & 33 & 3356 & 20.18 & 5109 & & & & & & & & & & & & & & \\
\hline 2000 & 34 & 3297 & 21.29 & 5487 & 7.3 & 498 & 176 & 77 & -533 & 1037 & -1570 & 172 & 440 & 0 & 748 & 821 & 26 & 777 \\
\hline 2001 & 35 & 3203 & 22.55 & 5920 & 7.4 & 457 & 158 & 69 & -582 & 1014 & -1596 & 179 & 366 & 23 & 732 & 863 & 19 & 702 \\
\hline 2002 & 36 & 3186 & 24.22 & 6443 & 7.6 & 506 & 187 & 81 & -576 & 1058 & -1634 & 161 & 368 & 0 & 764 & 870 & 33 & 807 \\
\hline 2003 & 37 & 3186 & 25.44 & 6855 & 7.6 & 394 & 179 & 78 & -476 & 884 & -1361 & 176 & 298 & 124 & 638 & 722 & 27 & 678 \\
\hline 2004 & 38 & 3161 & 26.23 & 7138 & 6.9 & 314 & 178 & 74 & -483 & 1002 & -1485 & 180 & 283 & 100 & 723 & 762 & 71 & 629 \\
\hline 2005 Apr. & 39 & 2600 & 19.61 & 5259 & 4.6 & 388 & 136 & 59 & -291 & 786 & -1077 & 173 & 259 & 49 & 567 & 509 & 32 & 614 \\
\hline 2005 Dec. & & 2600 & 20.82 & 5647 & & & & & & & & & & & & & & \\
\hline Mean & & & & & 6.5 & 418 & 156 & 67 & -386 & 1011 & -1397 & 166 & 334 & 42 & 730 & 667 & 34 & 674 \\
\hline SD & & & & & 1.2 & 77 & 24 & 10 & 171 & 138 & 192 & 11 & 62 & 42 & 100 & 166 & 19 & 84 \\
\hline $\mathrm{CV} \%$ & & & & & 18 & 18 & 15 & 15 & 44 & 14 & 14 & 6 & 19 & 101 & 14 & 25 & 57 & 12 \\
\hline
\end{tabular}

area, and $5^{\circ} \mathrm{C}$ higher than the long-term average. Rainfall during the growing season (May to October) was either higher or lower than the long-term average, 1996 and 2003 being the driest years.

Years 1996 and 1997 were dry and moderately dry, respectively, according to estimated water stress duration (Tab. IV). In 1998, the onset of drought, even if it was not severe, occurred very early, at the beginning of July. Years 1999, 2000 and 2002 were wet, while Years 2003 and 2004 were exceptionally dry; 2003 was one of the 2 driest years for the last 60 years.

\subsection{Stand condition and management}

Due to its young age and the high fertility conditions, the stand investigated showed a rapid biomass increase of about 

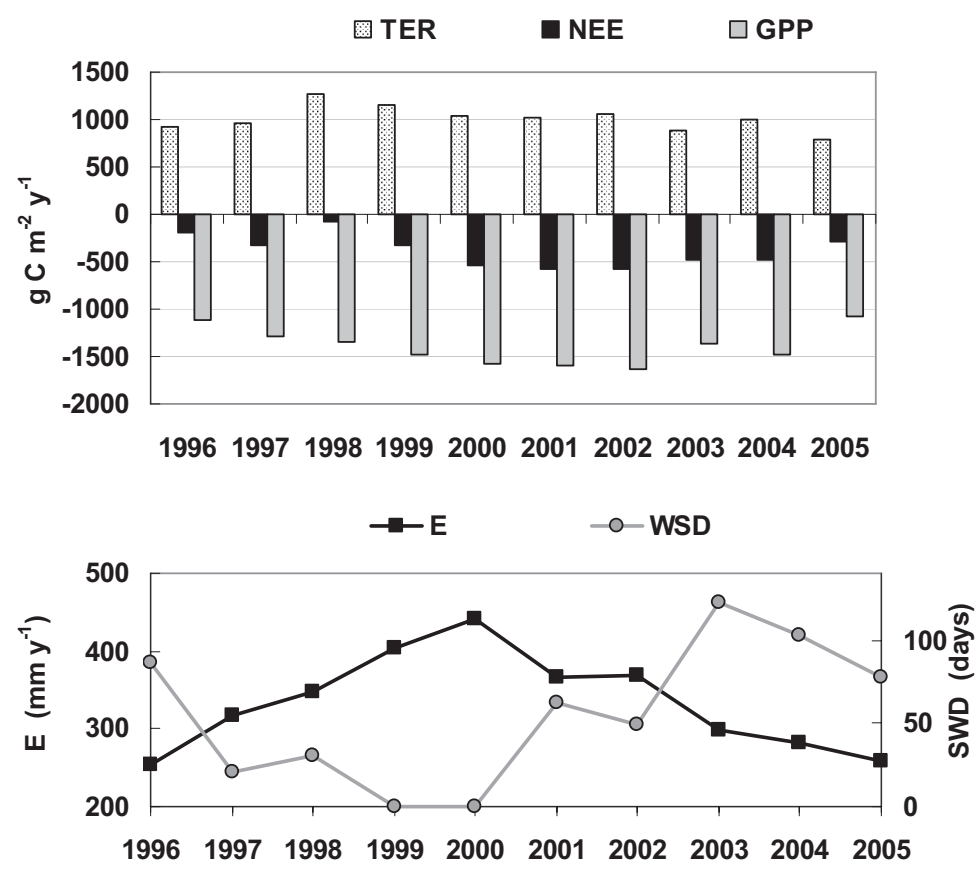

Figure 2. Top: annual net ecosystem exchange (NEE), gross primary production (GPP) and total ecosystem respiration (TER) for the 10 years of measurements at Hesse. Bottom: annual evapotranspiration (E) and soil water deficit duration (SWD).

$+7 \%$ per year: therefore the total stand biomass doubles every 10 years.

During the winters 1995-1996, 1998-1999 and 2004-2005, the stand was thinned. At each thinning operation, about $25 \%$ of the basal area was felled; tree trunks were removed, while branches and small diameter stems (diameter $<7 \mathrm{~cm}$ ) were left on the ground.

Leaf area index varied from 4.6 (in 2005) to 7.6 (in 2002 and 2003). The lower LAI values, observed in 1996, 1999 and 2005, resulted from thinning. LAI recovery after thinning was very fast (1 to 2 years).

\subsection{Annual carbon and water fluxes, and stand growth}

\subsubsection{Water fluxes}

The annual evapotranspiration (E, Fig. 2 and Tab. IV) ranged between 254 and $440 \mathrm{~mm}(\mathrm{CV}=19 \%)$. E showed a year-to-year increase from 1996 to 2000 and thereafter, a decrease. E was significantly correlated with LAI and with the soil water deficit duration during the vegetation period (SWD, in days):

$$
\begin{aligned}
& \mathrm{E}=239+22.1 \mathrm{LAI}-1.12 \mathrm{SWD} \\
& \qquad\left(r^{2}=0.72, p<0.05, n=10\right)
\end{aligned}
$$

The negative effect of SWD on E is shown at the bottom of Figure 2.

\subsubsection{Carbon fluxes}

NEE (Fig. 2 and Tab. IV) exhibited a much larger interannual variability than $\mathrm{E}$, ranging between -76 and $-582 \mathrm{~g} \mathrm{C} \mathrm{m}^{-2}$ $\mathrm{y}^{-1}$, with an average value of $-386 \mathrm{~g} \mathrm{C} \mathrm{m}^{-2} \mathrm{y}^{-1}$. The $\mathrm{CV}$ of NEE was $44 \%$, while it was only $14 \%$ for both TER and GPP, i.e. comparable with the E variability. The carbon sequestration was particularly low in 1998 compared to the average: this resulted from abnormally high ecosystem respiration.

NEE was significantly correlated $(p<0.01)$ to the length of the growing season (GSL) and to its end date. It is worth noting that GSL showed a significant increase at Hesse (1.9 days $\left.\mathrm{y}^{-1}\right)$ during the 10 years of observation, mainly due to an increase of the end date.

The gross assimilation (GPP) showed a year-to-year increase from 1996 (dry year) to 2000, with an increase of more than $500 \mathrm{~g} \mathrm{C} \mathrm{m}^{-2} \mathrm{y}^{-1}$ over the 5 years. This period followed the first thinning (1995) performed in this stand. From 2000 to 2002 , GPP stabilized to about $-1600 \mathrm{~g} \mathrm{C} \mathrm{m}^{-2} \mathrm{y}^{-1}$. In 2003, GPP suddenly decreased in relation to a long, severe summer drought. Annual GPP was significantly correlated $(p<0.01)$ to SWD and to the length of the growing season. The temporal patterns of E and GPP were similar, indicating a more or less proportional variation. However, we found a linear relationship $(p<0.05)$ between the ratio GPP/E (i.e. the canopy water-use efficiency) and SWD (Fig. 3).

Annual TER was moderately negatively correlated to water stress intensity ( $p=0.05$ ) but not to its duration. Surprisingly, TER was not correlated to the mean annual soil temperature, and in addition, within each year the soil temperature explained about $75 \%$ of the hourly and the daily variations 


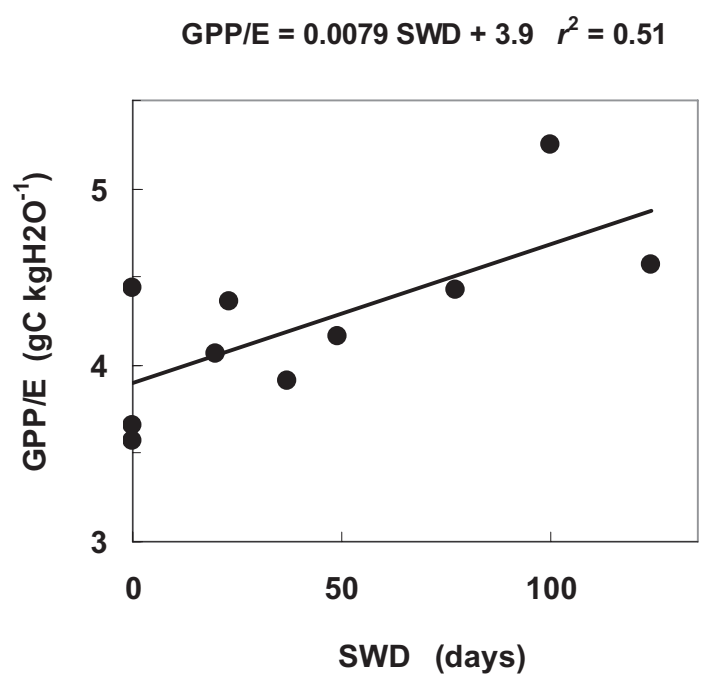

Figure 3. Linear regression between the ratio of gross assimilation and evapotranspiration (GPP/E) as a function of soil water deficit duration (SWD).

(data not shown). The ratio of TER to GPP was very variable from year to year, from 0.61 to 0.94 with a mean value of 0.72 . There was a moderate linear relationship between TER and GPP $\left(r^{2}=0.25\right)$; excluding the year 1998, this regression was much better $\left(r^{2}=0.58, p=0.01\right)$.

The thinning of 1999, even though it was severe, which occurred before a wet season, did not seem to impact annual fluxes: while leaf area index was sharply reduced from 7.4 in 1998 to 4.8 in 1999, no decreases, either in E, NEE or in GPP, were observed.

\subsection{Trees and stand growth}

\subsubsection{Annual variation of NEE and tree growth}

The interannual variation of annual biomass increment and NEE is shown in Figure 4. The relationship between both variables was not significant and moreover the regression slope was very different from 1 . At the beginning of the measurements, the annual net carbon uptake was lower than BI (1996 to 1999 , and particularly in 1998) and then it was higher (2000 to 2004). Despite a large discrepancy between both estimates, cumulated values over the 10 years were close: $3858 \mathrm{~g} \mathrm{C} \mathrm{m}^{-2}$ and $4183 \mathrm{~g} \mathrm{C} \mathrm{m}^{-2}$, for $\mathrm{NEE}$ and $\mathrm{BI}$, respectively (i.e. a $7 \%$ difference).

The interannual variability in biomass increment was much lower $(\mathrm{CV}=18 \%)$ than that of NEE. This variability was significantly related to SWD during the growing season (Fig. 5):

$$
\begin{aligned}
& \mathrm{BI}\left(\mathrm{gCm}^{-2} \mathrm{a}^{-1}\right)=477-1.36 \mathrm{SWD} \\
& \quad\left(r^{2}=0.60, p<0.01, n=10\right)
\end{aligned}
$$

However, in Figure 5 it can be seen that the biomass increment in 2003 was much larger than expected under such

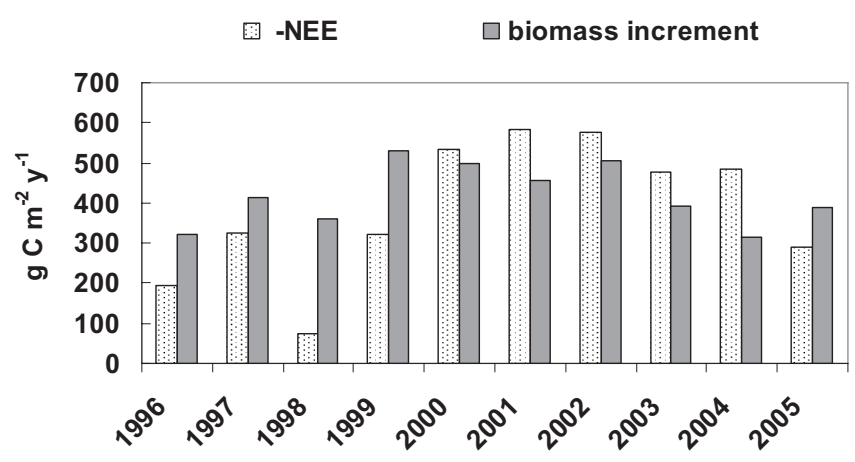

Figure 4. Variation of the total annual tree biomass increment (BI) and net ecosystem exchange (-NEE) during the 10 years of measurements at the Hesse beech forest.

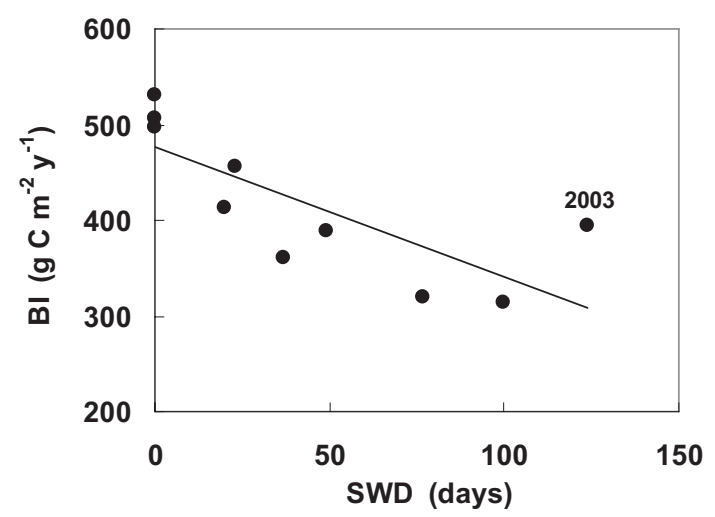

Figure 5. Relationship between annual biomass increment and soil water deficit duration during the growing period (SWD).

severe soil water deficit conditions. The regression was improved $\left(r^{2}=0.68\right)$ when including the soil water deficit duration of the preceding year $\left(\mathrm{SWD}_{n-1}\right)$.

A stronger relationship $\left(r^{2}=0.74, n=10\right)$ was obtained with GPP, LAI and $\mathrm{SWD}_{n-1}$ :

$$
\mathrm{BI}=283.4-0.394 \times \mathrm{GPP}-58.1 \times \mathrm{LAI}-0.948 \times \mathrm{SWD}_{\mathrm{n}-1}
$$

Therefore, as expected, biomass increment increases with GPP (note that here GPP is negative), which itself increases with LAI (GPP $=-709-106$ LAI, $\left.r^{2}=0.42, p<0.05\right)$. The surprising negative residual effect of LAI on BI is driven by low LAI values. It can be explained by a better canopy efficiency after thinning. Then, the soil water deficit duration of the previous year is also significant and highlights the differed effect of water stress on tree growth.

\subsubsection{NPP estimates}

In order to attempt to reduce the discrepancy between the two estimates of carbon sequestration (i.e. fluxes and tree biomass), we calculated the annual net primary production (NPP) using two approaches: (i) NPP of the ecosystem 


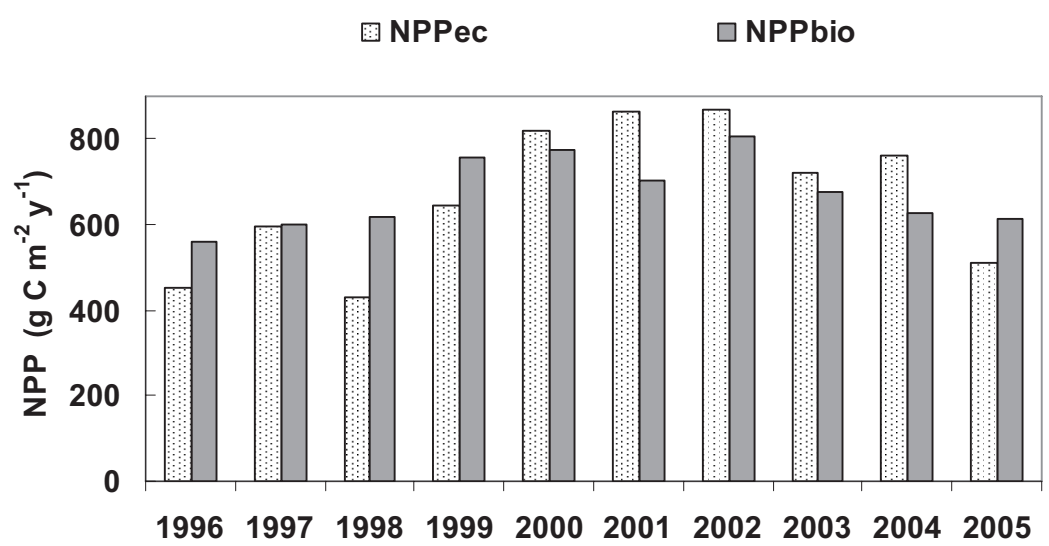

Figure 6. Variation of annual NPP at Hesse from 1996 to 2005, as estimated from: (i) eddy covariance measurements (NPPec), and (ii) biometric measurements (NPPbio, see text).

(NPPec) was calculated from the above-canopy flux measurements: NPPec $=-$ GPP - Raut, where Raut was the ecosystem autotrophic respiration. We assumed that Raut was equal to $72.2 \%$ of the total ecosystem respiration, a value obtained from a previous study in the same stand (Granier et al., 2000b); (ii) Biological NPP (NPPbio) was estimated from stand-scale biomass measurements: NPPbio $=\mathrm{BI}+\mathrm{P}_{\mathrm{L}}+\mathrm{P}_{\mathrm{R}}+\mathrm{P}_{\mathrm{F}}+\mathrm{M}$, where: $\mathrm{P}_{\mathrm{L}}, \mathrm{P}_{\mathrm{R}}$ and $\mathrm{P}_{\mathrm{F}}$ are the leaf, fine root and fruit production, respectively, and $\mathrm{M}$ is the woody mortality. We assumed (Granier et al., 2000b) that $\mathrm{P}_{\mathrm{R}}$ amounted to $43.5 \%$ of the annual leaf production. Annual values of both NPP estimates are presented in Table IV. The two NPP estimates agreed better than NEE vs. BI (Fig. 6). Over 10 years, mean values of NPPec and NPPbio were very close: the difference was only $1 \%$.

Figure 7 shows the distribution of the assimilated carbon GPPbio ("biological" GPP, $1404 \mathrm{~g} \mathrm{C} \mathrm{m}^{-2}$ on average), calculated as GPPbio $=$ Raut $+\mathrm{BI}+\mathrm{P}_{\mathrm{L}}+\mathrm{P}_{\mathrm{R}}+\mathrm{P}_{\mathrm{F}}+\mathrm{M}$, into the different pools. More than $50 \%$ of GPPbio is lost by autotrophic respiration, while less than $30 \%$ is allocated to the increment of woody tree compartments, of which only about $60 \%$ has a commercial value and is therefore exported from the stand (= $18 \%$ of GPPbio).

\subsubsection{Seasonal variation of $\mathrm{NEE}$ and tree growth}

We have shown above, that on an annual basis, NEE and biomass increments were not significantly correlated. We analysed the seasonal time-courses of the biomass increments, estimated from tree circumference measurements and cumulated NEE. Both agreed very well during the fast growing period, lasting from about DOY 120 to 180 . This is illustrated in Figure 8 for 3 contrasting years: 2000 (wet), 2003 (dry) and 2005 (moderately-dry following two dry years). Then, a deviation appeared and increased when growth slowed down and then stopped, (from DOY 192 to 252, depending on the years), while the forest ecosystem continued to absorb carbon. The date of divergence between both courses was different depending on the year, being earlier in a dry year (2003) than in a wet year (2002 or 2005).

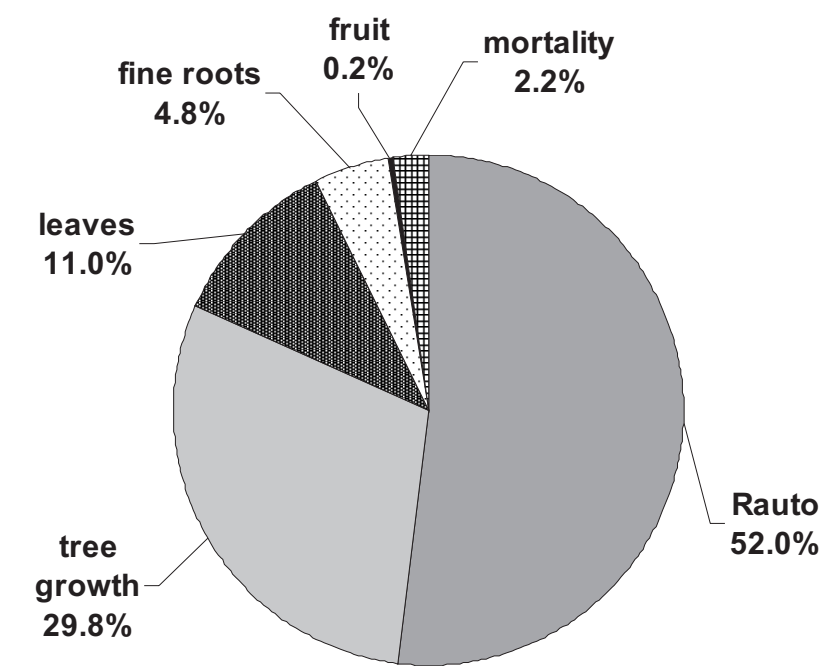

Figure 7. Fate of the assimilated carbon (GPPbio, see text) at the Hesse site. Mean values, calculated for 10 years of fluxes and biomass measurements.

For each year, we compared the intra-annual biomass increment (over 7 to 14 days) with the cumulated NEE (Fig. 9) from the beginning of carbon uptake (i.e. the date of NEE inversion). During the fast radial growth period, the relationship was linear and close to $1: 1$, indicating a strong link between carbon uptake and tree growth. During this period, lasting from 2 to 3.5 months depending on the years, we obtained the following relationship:

$$
\mathrm{BI}=0.96 \mathrm{NEE}+26 \quad\left(r^{2}=0.96, n=28\right)
$$

\section{DISCUSSION}

\subsection{Water fluxes}

Annual water vapour flux (E) was mainly explained by: (i) soil water deficit duration during the vegetation period, 

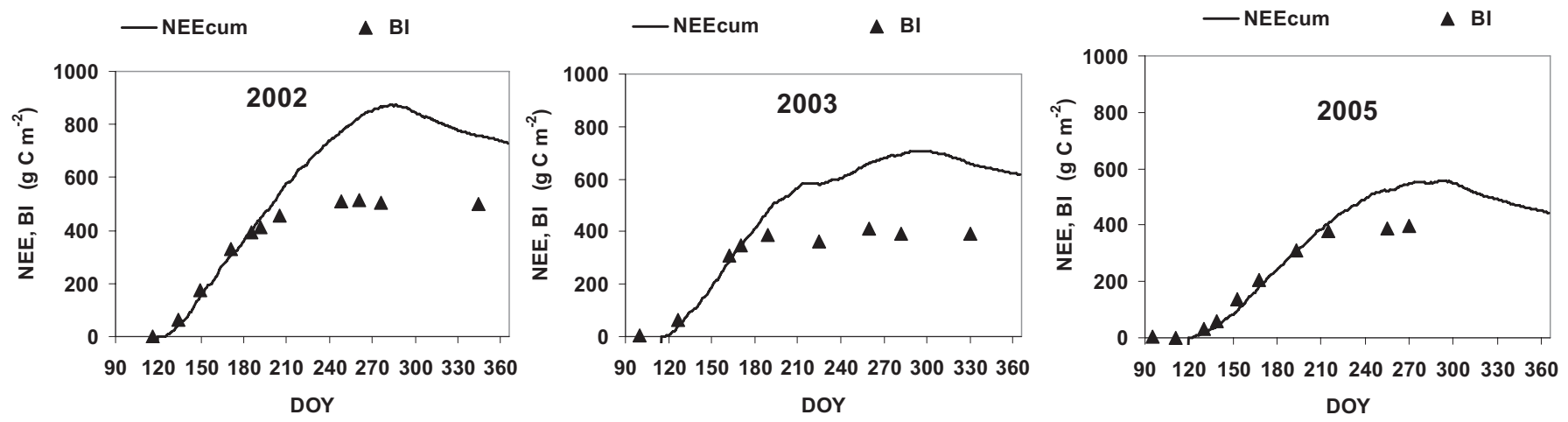

Figure 8. Time-course of cumulated NEE and of biomass increment (BI), estimated from periodic circumference measurements at Hesse. Examples for a wet year (2000, left), a dry year (2003, middle) and a moderately-dry year (right) consecutive to two very dry years.

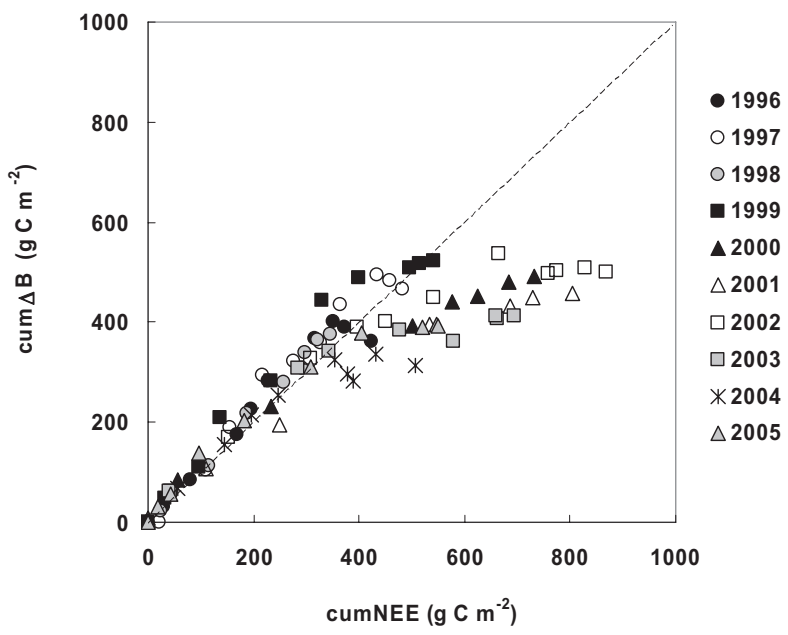

Figure 9. Cumulated biomass increment, estimated from the manual circumference measurements, as compared to cumulated NEE. Within each year, the beginning is set to the date of NEE inversion.

due to a strong stomatal control in beech by soil water content (Granier et al., 2000b) and (ii) LAI, that itself influenced the canopy conductance to water vapour. No significant correlation of annual $\mathrm{E}$ with other environmental variables was found, even if on a daily or hourly basis, water vapour flux was well correlated with net radiation, vapour pressure deficit and therefore to potential evapotranspiration (data not shown). Such lack of correlation for the annual values is mostly due to a low interannual variability in the evaporative demand: the coefficient of variation of the potential evapotranspiration was only $14 \%$.

\subsection{NEE}

At Hesse, we found a large interannual variability of NEE. As a comparison, the mixed deciduous temperate forest of Harvard (Barford et al, 2001), where average NEE was -201 g $\mathrm{C} \mathrm{m}^{-2} \mathrm{y}^{-1}$, showed less interannual variability over 9 years of monitoring $(\mathrm{CV}=18 \%)$. The main source of this variability was attributed to the growing season length (GSL). In a boreal Scots pine forest, Suni et al. (2003) also reported a low interannual variability in NEE, which was mainly related to the temperature. In a coniferous - deciduous mixed forest, Carrara et al. $(2003 ; 2004)$ attributed the large internannual variability to both GSL and to the annual temperature. At Hesse, the GSL varied in the range 152 to 180 days and increased significantly during the 10 years $\left(+1.9\right.$ day $\left.\mathrm{y}^{-1}\right)$, while Piao et al. (2007) found an average increase in the Northern hemisphere during the last 25 years $\left(+0.36\right.$ day $\left.^{-1}\right)$. In beech, GSL is much more influenced by the senescence date than by the budburst date, the latter being more dependent on daylight duration than on temperature (Nielsen and Jørgensen, 2003). We found a significant relationship between NEE and GSL $(p<0.02)$. Surprisingly, NEE was not significantly correlated to soil water deficit duration or intensity, perhaps partly because NEE outside the growing season is not drought dependent. However, a different picture was obtained when looking at daily or monthly NEE data. For example, NEE decreased strongly (in absolute value) from July to September 2003 (data not shown) as compared to the same period in 2002. Ciais et al. (2005) and Granier et al. (2007) reported this decrease in NEE from June to September 2003 at the European scale.

\subsection{GPP, TER, NPP and soil respiration}

NEE variation results from variations in both GPP and TER; therefore, analysis of the behaviour of each of these two elementary fluxes is necessary in order to get more mechanistic information. GPP decreased (in absolute value) with soil water deficit duration and intensity, and increased with GSL. The effect of LAI was not significant, and GPP was related to neither annual nor growing season global radiation, probably because radiation showed only a very limited variation from one year to another $(\mathrm{CV}<6 \%)$. The GPP increase from 1996 to 2002 resulted from the soil water deficit decrease during this period. The decrease in GPP since 2003, as a consequence of NEE, can be explained by a sequence of two consecutive very dry years (2003 and 2004), followed by 2005 which was a moderately dry year. Pereira et al. (2007) also reported this 
delayed effect of drought on GPP and NEE in a eucalyptus plantation.

Besides the impact of water stress on gross photosynthesis, it is worth noting that the atmospheric $\mathrm{CO}_{2}$ concentration increased significantly during this 10 -year period: $+25 \mathrm{ppm}$ $(=+7 \%$, i.e. a larger increase than at the Mauna Loa monitoring station). Even if an increase in $\mathrm{CO}_{2}$ concentration should enhance photosynthesis, this effect could not be observed clearly here, because: (i) the period of observation was rather too short, and therefore the $\mathrm{CO}_{2}$ concentration increase was limited, and at the same time the other environmental factors also varied to a large extent during this period; and (ii) most plants acclimate to some extent to $\mathrm{CO}_{2}$ enrichment, as reported from controlled-conditions and from in situ FACE experiments on trees (Ainsworth and Long, 2005).

Except for a moderate correlation between TER and soil water deficit duration, we did not find significant correlations with any other environmental or structural stand variables. This is the result of more complexity in TER determinism than for E or GPP: TER involves fluxes from a range of aerial and below-ground ecosystem compartments, each responding to different mechanisms and variables. For instance, autotrophic respiration of living tissues is linked to growth and to maintenance functions and heterotrophic respiration is dependent on microbial decomposition activities. TER can be enhanced when either autotrophic or heterotrophic respiration increase. In our stand, a significant proportion of the heterotrophic respiration originated from the decomposition of woody debris remaining on the forest floor after thinning, in addition to leaf litter and soil organic matter. Ngao (2005) estimated this annual carbon flux as $60 \mathrm{~g} \mathrm{C} \mathrm{m}^{-2}$. A combination of favourable environmental conditions during a period of the year can enhance the annual ecosystem respiration. For instance, a much higher TER than average was observed in 1998 due to an exceptional respiration peak in September, which was also observed in another beech forest in Denmark (Granier et al., 2002). This period of high TER was characterized by warm temperatures and frequent low rainfall events at both beech sites. Therefore, careful analysis at a shorter time-scale is necessary to analyse the interannual variability.

The year-to-year variation of the TER/GPP ratio was large. On average, it equalled $0.74( \pm 0.20, p=0.05)$ at Hesse. It was lower than values found in other broadleaved forests: 0.84 at Harvard over 9 years (Barford et al., 2001), and 0.86 in the European beech forest of Sorø (Pilegaard et al., 2001). Janssens et al. (2001) found a mean ratio of 0.80 in $18 \mathrm{Eu}-$ ropean ecosystems and Law et al. (2002) obtained 0.83 (0.55 to 1.2) over a wide range of ecosystem types, including grasslands and crops. Soil respiration is generally the largest TER component in forests and influences NEE to a large extent. From soil respiration measurements using chambers in 1996, 1997 (Epron et al., 1999a; Granier et al., 2000b), 2003 and 2004 (Ngao, 2005), Rs/TER was on average 0.64 at Hesse ( 0.58 to 0.69 ), i.e. close to the mean value of 0.69 found in 18 European forests by Janssens et al. (2001). As for TER, at Hesse Epron et al. (2004) found that Rs exhibited a large interannual variation that was not fully explained by soil temperature and water content variation; the effect of thinning was hypothesized in this study. At our site, autotrophic soil respiration alone, i.e. mainly the root respiration, represented $64 \%$ of Rs (mean of 3 years, Epron et al., 1999b; Ngao, 2005).

The absence of a significant correlation between the annual NEE and drought duration or intensity, is explained by a compensating effect, because drought decreases both GPP and TER. For the same reason, we found that the severe 2003 summer drought had more impact on GPP than NEE (Granier et al., 2007).

Following our assumptions, in particular on the annual fine root production estimates, the ratio of NPP to GPP over the 10 years of measurement was in the range 0.40 to 0.54 with a mean of 0.47. Waring et al (1998) obtained similar values for 12 various forest ecosystems in the USA, Australia and New Zealand. Therefore, more than half of the assimilated carbon is lost by respiratory processes.

\subsection{WUE}

The canopy water-use efficiency, defined as the GPP/E ratio, varied between 3.56 and $5.25 \mathrm{~g} \mathrm{C} \mathrm{kgH}_{2} \mathrm{O}^{-1}$, and showed a linear increase with soil water deficit duration or intensity (Fig. 3). This drought-induced increase in WUE has often been reported indirectly in trees including beech (Dupouey et al., 1993), by stable isotopes studies in tree rings showing a $\delta^{13} \mathrm{C}$ increase with drought, which is proportional to WUE. NPPbio/E showed a significant relationship with $\operatorname{SWD}\left(r^{2}=0.69\right.$, $p=0.003$ ), while BI/E, did not. This may be due to the growth timing: in this stand with a high soil water holding capacity, drought onset occurred late in the growing season, when a large part of the annual increment had been achieved.

\subsection{Thinning and fluxes}

As for NEE, thinning reduced neither GPP nor TER, even after the severe 1999 thinning that reduced LAI from 7.4 to 4.8. In a young Pinus ponderosa plantation, Misson et al. (2005) observed a decrease in GPP but not in TER. However, their stand was characterized by a very low LAI (about 1.5) indicating that most of the needles were sun-exposed. In our case, thinning was performed under very dense canopy conditions. Consecutive to thinning, the remaining trees intercepted more radiation, especially their lower crowns, thus enhancing tree photosynthesis. In a 16-year-old Pinus taeda plantation, Tang et al. (2003) demonstrated that thinning increased the photosynthesis and transpiration of the newly exposed needles by more than $25 \%$.

The exceptional storm of 26th December 1999, with a peak wind speed of $156 \mathrm{~km} \mathrm{~h}^{-1}$, after which the measurement tower fell down, had no effect on fluxes, since the trees were not damaged within the eddy flux foot-print area, while older beech and oak stands located further away were partially or totally destroyed. 


\subsection{Tree biomass increment and delayed effects of drought}

Due to its young age and the high site fertility, this stand is characterized by a rapid increase in tree biomass: from 1996 to 2005 , the standing biomass increased by $16 \%$. When adding the biomass of the thinned trees, the increase over 10 years reached $85 \%$. European yield tables for beech state that maximum stand productivity is at about 60 years old, with a nearly linear increase between 30 and 50 years old. The Hesse stand is therefore still in its increasing growth rate phase.

The correlation between annual NEE and stand biomass increment (Fig. 4) was poor: in some years the difference was as large as $100 \mathrm{~g} \mathrm{C} \mathrm{m}^{-2} \mathrm{y}^{-1}$. In a study performed in five North American deciduous forests (Curtis et al., 2002), such discrepancies were observed between NEE and BI, with the largest difference being $220 \mathrm{~g} \mathrm{C} \mathrm{m}^{-2} \mathrm{y}^{-1}$. In a North American mixed deciduous forest, Ehman et al. (2002) reported estimates of carbon uptake from inventories to be 34 and $90 \mathrm{~g}$ $\mathrm{C} \mathrm{m} \mathrm{m}^{-2} \mathrm{y}^{-1}$ higher for two successive years, than from eddy covariance measurements. In a mixed hardwood forest, both estimates agreed within 5\% (Schmid et al., 2000). In a Sitka spruce forest, Black et al. (2007) found a significantly higher carbon stock increment, as estimated from inventories, than NEE: they suggested that this discrepancy was due to biomass decomposition and to soil carbon stock change. In an aspen dominated mixed-deciduous American forest, Gough et al. (2007) found similar results to ours: a poor agreement between annual NEE and biometric estimates, and very close one (1\% difference) over a 5-year period. On the annual time scale, an initial explanation of such discrepancies is that NEE includes the heterotrophic respiration fluxes, originating from the soil and the various above-ground compartments: leaf litter, fine roots, natural and man-induced mortality. Carbon fluxes coming from these compartments probably have contrasting decomposition kinetics according to the nature of the substrate. For instance, branch decomposition takes more than five years (Jérôme Ngao, pers. comm.). Considering NPP, our two independent estimates were in much better agreement, because NPP takes into account both turnover and mortality terms. However, there is much uncertainty regarding the quantification of natural mortality as the litterbags used were not very suitable for large branch collection. Moreover there was also a large incertitude concerning the fine-root turnover. In addition to other explanations like herbivory or methane losses, many uncertainties can affect both estimates. First, the eddy covariance technique could be suspect, due to low turbulence during the night or to rainfall on the EC sensors. There were also a number of potential sources of error in estimating tree biomass and its annual increment: tree sample representativity, as compared to the foot-print area of the eddy covariance measurements, and the use of the same allometric functions every year, whatever the conditions (drought, thinning, etc.), that could modify the carbon allocation pattern in trees.

Besides this large discrepancy between annual biomass increment and NEE, intra-annual courses were remarkably close during the fast increment period. This suggests that, during this period, there is a strong link between carbon uptake and its allocation to the stem growth, and that the allocation coefficient to the stems is constant. Later on in the growing season, a sudden divergence between growth and carbon uptake appeared earlier or later in the summer, between DOY 178 (in 2003) and DOY 266 (in 1999). However, one has to careful with regard to this timing, as we assumed that volume and biomass increment were proportional, i.e. that wood density was constant. There could be an increase in wood density after radial growth cessation, as suggested by the impact of September photosynthesis on late wood density in beech tree rings (Bouriaud et al., 2004), that might change the NEE vs. biomass increment relationship to some extent. Our hypothesis of constant allocation coefficients to tree organs would also have similar consequences.

The 2003 and 2004 droughts provoked a decrease in GPP and therefore in tree growth. Compared to 2002, a wet year, the circumference increments were 32, 49 and $11 \%$ lower in 2003, 2004 and 2005, respectively. The corresponding decreases in annual biomass increments were $22 \%, 38 \%$ and $23 \%$ for these 3 years. Furthermore, in 2004, large quantities of beech mast were observed, probably enhanced by the 2003 and 2004 droughts (Piovesan and Adams, 2005) that also affected biomass increment. As the trees get older, mast production increases and therefore has a negative effect on tree growth in some years, due to competition between growth and seed production. The important growth decline in 2005 resulted from both a lower circumference increment combined with reduced stand density after thinning. We found (Eq. (3)) that annual biomass increment depended significantly on the current year GPP and LAI, and on the previous year soil water deficit duration. This drought-delayed effect is also seen on the increment slope during the fast growing period (May and June) that determines the annual biomass growth $\left(r^{2}=0.72\right.$, $p=0.002)$ : this slope was influenced by the drought of the previous year. The lowest slope was observed in 2004, i.e. after a very dry year.

Within each year, after the cessation of radial growth (average DOY 217), there is a long period during which trees store reserves in their living organs, until the time when the carbon balance reverses (average DOY 287), i.e. for more than 2 months. During this period, the ecosystem stored on average $94 \mathrm{~g} \mathrm{C} \mathrm{m}^{-2}$ (range 20-210 $\mathrm{g} \mathrm{C} \mathrm{m}^{-2}$ ). The leaf production, and hence LAI, was well correlated $\left(r^{2}=0.78\right.$, $p<0.01)$ to the biomass increment in the previous year. This probably results from bud preformation in beech: leaf primordia are initiated in buds during the preceding year, from May to September (Roloff, 1985). As a consequence of storage/remobilization mechanisms (Barbaroux and Bréda, 2002), the year-to-year variation in biomass increment due to abiotic and biotic stresses as compared to GPP variation, is probably buffered .

\section{CONCLUSION}

Despite the high interannual variability in weather conditions, the 10-year study period was characterised by: (1) a mean annual temperature which was always higher than the 
long-term average, (2) a succession of dry years, and (3) a steady increase in the concentration of atmospheric $\mathrm{CO}_{2}$.

Over this period, we found a close agreement between cumulated NEE and tree growth, but on an annual timescale the relationship between both parameters was very poor. We explained this by delayed carbon storage and release mechanisms in the ecosystem compartments. Therefore, stand growth is more closely linked to NPP than to NEE.

In the young fast-growing Hesse beech stand, drought and management explained most of the interannual variability in fluxes and tree growth. The importance of drought is surprising, since the forest investigated receives a quite high annual rainfall and furthermore, is growing on a soil with a high water holding capacity. However, in temperate regions, as opposed to dry regions, summer water deficit often shows a high temporal variability. Moreover, temperate tree species like European beech are not well adapted to drought and therefore react markedly to drought events.

We also showed a strong link between carbon uptake by trees and growth on a seasonal scale. However, the storage and remobilisation mechanism buffers the interannual variation of tree growth.

The second major source of variation in fluxes and forest growth is the management: the forest is thinned frequently at Hesse in order to stimulate tree growth. A direct consequence of thinning is a reduction in LAI of about $2-3 \mathrm{~m}^{2} \mathrm{~m}^{-2}$, but after thinning LAI recovery is very fast. Thinning stimulates photosynthesis and reduces soil water deficit, both of which improve biomass increment. After thinning, we observed that radial growth of the remaining trees was enhanced: for instance, radial growth was $45 \%$ higher in 1999 than the average radial growth over 10 years.

Acknowledgements: This work was supported by three successive European programmes Euroflux (ENV4-CT95-0078), Carboeuroflux (EVK2-1999-00229), Carboeurope-IP (505572); and also the French Forest Service (ONF), CNRS (Programme Environnement, Vie et Sociétés), GIP-Ecofor and ORE-F-ORE-T. The authors thank all the technical staff who performed the huge numbers of measurements at Hesse during the ten years (soil water content, tree circumference, biomass, litter collection, etc.). We thank particularly Bernard Clerc, François Willm, Pascal Courtois, and René Canta. We would also like to thank warmly Jean-Marc Ottorini and Noël Le Goff who invested so much time on biomass and allometric studies at Hesse.

\section{REFERENCES}

Ainsworth E.A. and Long S.P., 2005. What have we learned from 15 years of free-air $\mathrm{CO}_{2}$ enrichment (FACE)? A meta-analytic review of the responses of photosynthesis, canopy properties and plant production to rising $\mathrm{CO}_{2}$. New Phytol. 165: 351-371.

Aubinet M., Grelle A., Ibrom A., Rannik Ü, Moncrieff J., Foken T., et al., 2000. Estimates of the annual net carbon and water exchange of forests: the EUROFLUX methodology. Adv. Ecol. Res. 30: 113-175.

Barbaroux C. and Bréda N., 2002. Contrasting distribution and seasonal dynamics of carbohydrate reserves in stem wood of adult ring-porous sessile oak and diffuse-porous beech trees. Tree Physiol. 22: 12011210.

Barford C.C., Wofsy S.C., Goulden M.L., Munger J.W., Pyle E.H., Urbanski S.P., et al., 2001. Factors controlling long- and short-term sequestration of atmospheric $\mathrm{CO}_{2}$ in a mid-latitude forest. Science 294: 1688-1691.

Black K., Bolger T., Davis P., Nieuwenhuis M., Reidy B., Saiz G., et al., 2007. Inventory and eddy covariance-based estimates of annual carbon sequestration in a Sitka spruce (Picea sitchensis (Bong.) Carr.) forest ecosystem. Eur. J. For. Res. 126: 167-178.

Bouriaud O., 2003. Analyse fonctionnelle de la productivité du hêtre: influences des conditions de milieu, de la structure du peuplement et du couvert, effets de l'éclaircie. Ph.D. dissertation, ENGREF-Nancy

Bouriaud O., Bréda N., Le Moguédec G., and Nepveu G., 2004. Modelling variability of wood density in beech as affected by ring age, radial growth and climate. Trees 18: 264-276.

Carrara A., Kowalski A.S., Neirynck J., Janssens I.A., Yuste J.C., and Ceulemans R., 2003. Net ecosystem $\mathrm{CO}_{2}$ exchange of mixed forest in Belgium over 5 years. Agric. For. Meteorol. 119: 209-227.

Carrara A., Janssens I.A., Yuste J.C., and Ceulemans R., 2004. Seasonal changes in photosynthesis, respiration and NEE of a mixed temperate forest. Agric. For. Meteorol. 126: 15-31.

Ciais P., Reichstein N., Viovy N., Granier A., Ogee J., Allard V., et al., 2005. Europe-wide reduction in primary productivity caused by the heat and drought in 2003. Nature 437 (7058): 529-533.

Curtis P.S., Hanson P.J., Bolstad P., Barford C., Randolph J.C., Schmid H.P., and Wilson K.B., 2002. Biometric and eddy-covariance estimates of annual carbon storage in five Noth American deciduous forests. Agric. For. Meteorol. 113: 3-19.

Dupouey J.L., Leavitt S., Choisnel E., and Jourdain S., 1993. Modelling carbon isotope fractionation in tree rings based on effective evapotranspiration and soil water status. Plant Cell Environ. 16: 939-947.

Ehman J.L., Schmid H.P., Grimmond C.S.B., Randolph J.C., Hanson P.J., Wayson C.A., and Cropley F.D., 2002. An initial intercomparison of micrometeorological and ecological inventory estimates of carbon exchange in a mid-latitude deciduous forest. Glob. Change Biol. 8: $575-589$.

Epron D., Farque L., Lucot E., and Badot P.M., 1999a. Soil CO $\mathrm{C}_{2}$ efflux in a beech forest: dependence on soil temperature and soil water content. Ann. For. Sci. 56: 221-226.

Epron D., Farque L., Lucot E., and Badot P.M., 1999b. Soil $\mathrm{CO}_{2}$ efflux in a beech forest: the contribution of root respiration. Ann. For. Sci. 56: 289-295.

Epron D., Ngao J., and Granier A., 2004. Interannual variation of soil respiration in a beech forest ecosystem over a six-year study. Ann. For. Sci. 61: 499-505.

Gough C.M., Vogel C.S., Schmid H.P., Su H.B., and Curtis P.S., 2007. Multi-year convergence of biometric and meteorological estimates of forest carbon storage. Agric. For. Meteorol. available online 4 October 2007.

Granier A., Biron P., and Lemoine D., 2000a. Water balance, transpiration and canopy conductance in two beech stands. Agric. For. Meteorol. 100: 291-308.

Granier A., Bréda N., Biron P., and Villette S., 1999. A lumped water balance model to evaluate duration and intensity of drought constraints in forest stands. Ecol. Model. 116: 269-283.

Granier A., Pilegaard K., and Jensen N.O., 2002. Similar net ecosystem exchange of beech stands located in France and Denmark. Agric. For. Meteorol. 114: 75-82.

Granier A., Ceschia E., Damesin C., Dufrêne E., Epron D., Gross P., et al., 2000b. The carbon balance of a young beech forest. Funct. Ecol. 14: 312-325.

Granier A., Reichstein M., Bréda N., Janssens I., Falge E., Ciais P., et al., 2007. Evidence for soil water control on carbon and water dynamics in European forests during the extremely dry year: 2003. Agric. For. Meteorol. 143: 123-145. 
Hamilton G.J. and Christie J.M., 1971. Forest Management tables (metric). Londres: Her Majesty's Stationery Office.

Janssens I.A., Lankreijer H., Matteucci G., Kowalski A.S., Buchmann N., Epron D., et al., 2001. Productivity and disturbance overshadow temperature in determining soil and ecosystem respiration across European forests. Glob. Change Biol. 7: 269-278.

Law B.E., Falge E., Gu L., Baldocchi D.D., Bakwin P., Berbigier P., et al., 2002. Environmental controls over carbon dioxide and water vapor exchange of terrestrial vegetation. Agric. For. Meteorol. 113: 97120.

Misson L., Tang J., Xu M., McKay M., and Goldstein A., 2005. Influences of recovery from clear-cut, climate variability, and thinning on the carbon balance of a young ponderosa pine plantation. Agric. For. Meteorol. 130: 207-222.

Ngao J., 2005. Déterminisme de la respiration de l'écosystème dans l'étude du bilan de carbone d'une hêtraie de plaine. $\mathrm{PhD}$ dissertation, University of Nancy I.

Nielsen C.N. and Jørgensen F.V., 2003. Phenology and diameter increment in seedlings of European beech (Fagus sylvatica L.) as affected by different soil water contents: variation between and within provenances. For. Ecol. Manage. 174: 233-249

Ottorini J.M. and Le Goff N., 1998. Étude de la croissance du hêtre sur le plateau Lorrain. Convention de recherche ONF-INRA n ${ }^{\circ} 1136 \mathrm{~B}$.

Papale D., Reichstein M., Aubinet M., Canfora1 E., Bernhofer C., Kutsch W., et al., 2006. Towards a standardized processing of Net Ecosystem Exchange measured with eddy covariance technique: algorithms and uncertainty estimation. Biogeosciences 3: 571-583.

Pereira J.S., Mateus J.A., Aires L.M., Pita G., Pio C., David J.S., et al., 2007. Net ecosystem carbon exchange in three contrasting Mediterranean ecosystems - the effect of drought. Biogeosciences 4: 791-802.
Piao S., Ciais P., Friedlingstein P., Peylin P., Reichstein M., Luyssaert S., et al., 2008. Net carbon dioxide losses of northern ecosystems in response to autumn warming. Nature 451: 49-U3.

Pilegaard K., Hummelshøj P., Jensen N.O., and Chen Z., 2001. Two years of continuous $\mathrm{CO}_{2}$ eddy-flux measurements over a Danish beech forest. Agric. For. Meteorol. 107: 29-41.

Piovesan G. and Adams J.M., 2005. The evolutionary ecology of masting: does the environmental production hypothesis also have a role in mesic temperate forests? Ecol. Res. 20: 739-743.

Roloff A., 1985. Morphologie der Kronentwicklung von Fagus sylvatica L. (Rotbuche) under besonderer Berücksichtigung möglicherweise neariger Veränderungen. Ph.D. Thesis, Göttingen Univ., Göttingen, Germany.

Schmid H.P., Grimmond C.S.B., Cropley F., Offerle B., and Su H.B., 2000. Measurements of $\mathrm{CO} 2$ and energy fluxes over a mixed hardwood forest in the mid-western United States. Agric. For. Meteorol. 103: 357-374.

Schober R., 1987. Erstragstafeln wichtiger Baumarten. 3rd edition, Frankurt am Main: Sauerländer's Verlag, 166 p.

Suni T., Berninger F., Markkanen T., Keronen P., Rannik U., and Vesala T., 2003. Interannual variability and timing of growing-season $\mathrm{CO}_{2}$ exchange in a boreal forest. J. Geophys. Res. 108 (D9), 4265, doi:10.1029/2002JD002381.

Tang Z., Chambers J.L., Sword M.A., and Barnett J.P., 2003. Seasonal photosynthesis and water relations of juvenile loblolly pine relative to stand density and canopy position. Trees 17: 424-430.

Waring R.H., Landsberg J.J., and Williams M., 1998. Net primary production of forests: a constant fraction of gross primary production? Tree Physiol. 18: 129-134.

Wofsy S.C., Goulden M.L., Munger J.W., Fan S.M., Bakwin P.S., Daube B.C., et al., 1993. Net Exchange of $\mathrm{CO}_{2}$ in a Mid-Latitude Forest. Science 260: 1314-1317. 